\title{
THE STABILITY OF ANISOTROPIC CYLINDRICAL SHELLS UNDER TORSION IN SPATIAL POSITION*
}

\author{
Andrei Podvornyi ${ }^{\bowtie}$ \\ Institute of Building and Architecture, National University of Water and Environmental Engineering, Rivne
}

\begin{abstract}
In the present paper, an infinite system of homogeneous differential equations in the Cauchy normal form was obtained to solve the problem of the stability of cylindrical anisotropic layered shells under the action of external torque, based on the spatial relationship of elasticity theory. The components of the stress state that are necessary to solve the equation system were derived analytically by using the generalised Hooke's law. The results are obtained for a single-layer cylinder, and compared with the values of critical loads calculated using the well-known method proposed by Lechnitsky. The suggested approach could be implemented, for instance, to solve the problem of cylindrical two-layer shell stability under the action of torque, which is projected by calculating the shear stress.
\end{abstract}

Key words: cylinder, stability, anisotropy, torsion, spatial formulation

\section{INTRODUCTION}

Composite cylindrical shells are widely used in various designs of modern technology. Sometimes their operating conditions are such that shear stress occurs in the shells and can reach critical values. The magnitudes of these stresses could are known from previously performed tests or found by calculation. At present, methods for calculating composite shells in spatial formulation using mathematical models of varying degrees of accuracy have been developed (Novozhilov, 1948; Lekhnitskiy, 1977; Guz' \& Babich, 1985; Grigorenko, Vasilenko \& Pankratova, 1991; Kardomateas, 1995; Kardomateas \& Philobos, 1995; Bazhenov, Semenyuk \& Trach, 2010). In most studies, the structural idealisation of the composite determines that materials have three planes of symmetry. However, during the manufacturing of shells, for example, by means of winding there is an effect of anisotropy caused by the divergence of reinforcement directions to the shell axes (Bazhenov et al., 2010). Therefore, there is a need to develop methods aimed at solving the problems of composite shell stability using a more general model of a composite with low material symmetry.

In paper by Guz' and Babich (1985), the solutions for three-dimensional stability of orthotropic cylinders were presented, including the action of axial compressive force and uniform lateral pressure; and in articles by Kardomateas (1995), and Kardomateas and Philobos (1995), the buckling of orthotropic cylindrical shells in spatial formulation when determining the critical state using dependencies (Lekhnitskiy, 1977) is studied.

\footnotetext{
* Text was formatted in one-column page style due to complexity of the article. 
In the presented paper, a three-dimensional theory of elasticity to solve the problem of the composite anisotropic shell stability is considered (Novozhilov, 1948). The obtained three-dimensional solutions can serve as benchmarks in the calculations of stability of shell structures by numerical methods that are applicable to more complicated structural shapes, too.

\section{MATERIAL AND METHODS}

Elastic anisotropic composite cylindrical shells, assigned to the cylindrical (curvilinear) coordinate system $r, z, \theta$ are analysed. The axes $r$ and $\theta$ are the polar coordinates of the circular cross-section of the cylinder, $z$ is the corresponding cross-section, normal to the axis at the axis point, the origin of which coincides with the centre of the cylinder base. The geometry of the shell is determined by its length along the generatrix $L$, as well as by the radii of the inner $R_{1}$ and outer surfaces $R_{2}$, and is presented in Figure 1.

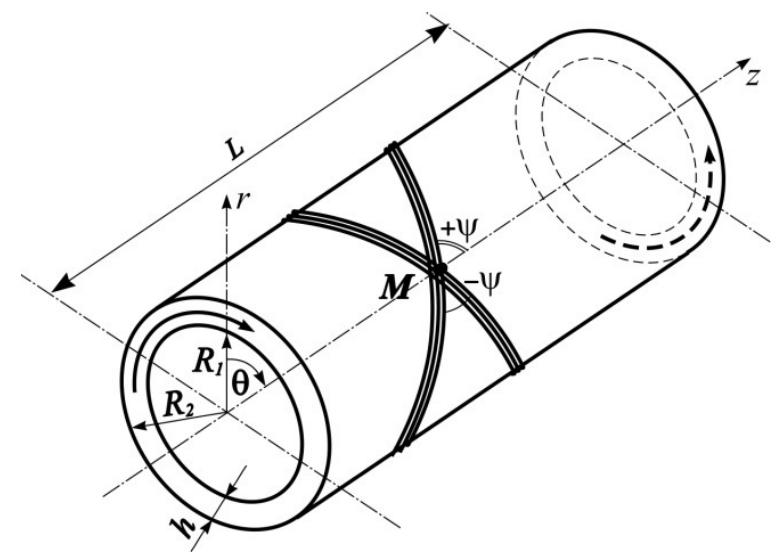

Fig. 1. A cylindrical thick-walled anisotropic shell

In the non-linear theory of elasticity (Novozhilov, 1948), the element equilibrium conditions for a cylindrical coordinate system are in three equations:

$$
\begin{aligned}
& \frac{\partial \hat{\sigma}_{r r}}{\partial r}=-\frac{1}{r}\left[\hat{\sigma}_{r r}+r \frac{\partial}{\partial z}\left(\hat{\tau}_{z r}\right)+\frac{\partial}{\partial \theta}\left(\hat{\tau}_{\theta r}\right)-\hat{\sigma}_{\theta \theta}+r F_{r}\right] \\
& \frac{\partial \hat{\tau}_{r z}}{\partial r}=-\frac{1}{r}\left[\hat{\tau}_{r z}+r \frac{\partial}{\partial z}\left(\hat{\sigma}_{z z}\right)+\frac{\partial}{\partial \theta}\left(\hat{\tau}_{\theta z}\right)+r F_{z}\right] \\
& \frac{\partial \hat{\tau}_{r \theta}}{\partial r}=-\frac{1}{r}\left[\hat{\tau}_{r \theta}+\hat{\tau}_{\theta r}+r \frac{\partial}{\partial z}\left(\hat{\tau}_{z \theta}\right)+\frac{\partial}{\partial \theta}\left(\hat{\sigma}_{\theta \theta}\right)+r F_{\theta}\right]
\end{aligned}
$$

in which $F_{r}, F_{z}, F_{\theta}$ are the vector projections of specific volumetric force on the directions tangent to the coordinate lines $r, z, \theta$, and $\hat{\sigma}, \hat{\tau}$ are the projections of stresses on the axis of the accepted curvilinear coordinate system of the undeformed shell, that are determined by dependencies (Novozhilov, 1948).

The linearised deformation components and the rotation angles of the shell are related to its displacements by the following dependencies: 


$$
\begin{aligned}
& e_{z z}=\frac{\partial u_{z}}{\partial z}, e_{\theta \theta}=\frac{1}{r} \frac{\partial u_{\theta}}{\partial \theta}+\frac{1}{r} u_{r}, e_{z \theta}=\frac{\partial u_{\theta}}{\partial z}+\frac{1}{r} \frac{\partial u_{z}}{\partial \theta} \\
& e_{r r}=\frac{\partial u_{r}}{\partial r}, e_{r \theta}=\frac{\partial u_{\theta}}{\partial r}-\frac{1}{r} u_{\theta}+\frac{1}{r} \frac{\partial u_{r}}{\partial \theta} \\
& e_{r z}=\frac{\partial u_{r}}{\partial z}+\frac{\partial u_{z}}{\partial r}, \omega_{z}=\frac{1}{2 r} \frac{\partial u_{r}}{\partial \theta}-\frac{1}{2 r} u_{\theta}-\frac{1}{2} \frac{\partial u_{\theta}}{\partial r} \\
& \omega_{\theta}=\frac{1}{2} \frac{\partial u_{z}}{\partial r}-\frac{1}{2} \frac{\partial u_{r}}{\partial z}, \omega_{r}=\frac{1}{2} \frac{\partial u_{\theta}}{\partial z}-\frac{1}{2 r} \frac{\partial u_{z}}{\partial \theta}
\end{aligned}
$$

where $u_{z}, u_{\theta}, u_{r}$ are the displacement of the cylinder points at the directions of the axes $z, \theta, r$, respectively.

The relationship of the generalised Hooke's law that connects stresses to strains in the rotation of the orthotropic axes relative to the axis $z$, can be given as (Lekhnitskiy, 1977):

$$
\begin{aligned}
& e_{z z}=a_{11} \sigma_{z z}+a_{12} \sigma_{\theta \theta}+a_{13} \sigma_{r r}+a_{16} \tau_{z \theta} \\
& e_{\theta \theta}=a_{12} \sigma_{z z}+a_{22} \sigma_{\theta \theta}+a_{23} \sigma_{r r}+a_{26} \tau_{z \theta} \\
& e_{r r}=a_{13} \sigma_{z z}+a_{23} \sigma_{\theta \theta}+a_{33} \sigma_{r r}+a_{36} \tau_{z \theta} \\
& e_{r \theta}=a_{44} \tau_{r \theta}+a_{45} \tau_{r z} \\
& e_{r z}=a_{45} \tau_{r \theta}+a_{55} \tau_{r z} \\
& e_{z \theta}=a_{16} \sigma_{z z}+a_{26} \sigma_{\theta \theta}+a_{36} \sigma_{r r}+a_{66} \tau_{z \theta}
\end{aligned}
$$

In (3) $a_{i j}(i, j=\overline{1,6})$ are the mechanical constants of a material having one plane of elastic symmetry that is parallel to the median surface of the cylinder. Their relation to the material constants, orthotropic axes of which coincide with the coordinate axes, is represented in paper by Lekhnitskiy (1977).

The relationship of the generalised Hooke's law for materials with one plane of elastic symmetry (3) is written in the inverse form (Grigorenko et al., 1991), which will be used to solve the system of equations (1):

$$
\begin{aligned}
& \sigma_{z z}=b_{11} e_{z z}+b_{12} e_{\theta \theta}+b_{16} e_{z \theta}+c_{1} \sigma_{r r} \\
& \sigma_{\theta \theta}=b_{12} e_{z z}+b_{22} e_{\theta \theta}+b_{26} e_{z \theta}+c_{2} \sigma_{r r} \\
& \tau_{z \theta}=b_{16} e_{z z}+b_{26} e_{\theta \theta}+b_{66} e_{z \theta}+c_{3} \sigma_{r r} \\
& e_{r r}=-c_{1} e_{z z}-c_{2} e_{\theta \theta}-c_{3} e_{z \theta}+c_{4} \sigma_{r r} \\
& e_{r z}=a_{45} \tau_{r \theta}+a_{55} \tau_{r z} \\
& e_{r \theta}=a_{44} \tau_{r \theta}+a_{45} \tau_{r z}
\end{aligned}
$$

where $b_{i j}(i, j=1,2,6), c_{i}(i=\overrightarrow{1,4})$ are the characteristics calculated by using the mechanical constant $a_{i j}(i, j=\overline{1,3}, 6)$ of the shell material. 
To solve the problem of the stability of cylindrical anisotropic shells, according to the Euler's static criterion, we linearised the system of equations (1) relative to derivatives by a change of variable $r$ (Semenyuk, Trach \& Podvornyi, 2019; Trach, Semenyuk \& Podvornyi, 2019). Therefore, we replace the stresses $\sigma_{z z}, \sigma_{\theta \theta}$, $\tau_{z \theta}$ by dependences (4) with the consideration of (2) and, using the ratio for deformation $e_{r z}, e_{r \theta}, e_{r r}$ (2); after the corresponding transformations, we obtain a system of stability equations for anisotropic thick-walled cylindrical shells:

$$
\begin{aligned}
\frac{\partial \sigma_{r r}}{\partial r}= & \frac{c_{2}-1}{r} \sigma_{r r}-\frac{\partial \tau_{r z}}{\partial z}-\frac{1}{r} \frac{\partial \tau_{r \theta}}{\partial \theta}+\frac{b_{22}}{r^{2}} u_{r}+\frac{b_{12}}{r} \frac{\partial u_{z}}{\partial z}+\frac{b_{26}}{r^{2}} \frac{\partial u_{z}}{\partial \theta}+\frac{b_{26}}{r} \frac{\partial u_{\theta}}{\partial z}+\frac{b_{22}}{r^{2}} \frac{\partial u_{\theta}}{\partial \theta}-\sigma_{z z}^{0} \frac{\partial^{2} u_{r}}{\partial z^{2}}-\frac{2}{r} \tau_{z \theta}^{0} \frac{\partial^{2} u_{r}}{\partial z \partial \theta}+\frac{2}{r} \tau_{z \theta}^{0} \frac{\partial u_{\theta}}{\partial z} \\
\frac{\partial \tau_{r z}}{\partial r}= & -c_{1} \frac{\partial \sigma_{r r}}{\partial z}-\frac{1}{r} \tau_{r z}-\frac{b_{12}}{r} \frac{\partial u_{r}}{\partial z}-b_{11} \frac{\partial^{2} u_{z}}{\partial z^{2}}-\frac{b_{66}}{r^{2}} \frac{\partial^{2} u_{z}}{\partial \theta^{2}}-\frac{b_{12}+b_{66}}{r} \frac{\partial^{2} u_{\theta}}{\partial z \partial \theta}-\frac{c_{3}}{r} \frac{\partial \sigma_{r r}}{\partial \theta}-\frac{b_{26}}{r^{2}} \frac{\partial u_{r}}{\partial \theta}-\frac{2 b_{16}}{r} \frac{\partial^{2} u_{z}}{\partial z \partial \theta}-b_{16} \frac{\partial^{2} u_{\theta}}{\partial z^{2}}- \\
& -\frac{b_{26}}{r^{2}} \frac{\partial^{2} u_{\theta}}{\partial \theta^{2}}-\sigma_{z z}^{0} \frac{\partial^{2} u_{z}}{\partial z^{2}}-\frac{2}{r} \tau_{z \theta}^{0} \frac{\partial^{2} u_{z}}{\partial z \partial \theta} \\
\frac{\partial \tau_{r \theta}}{\partial r}= & -\frac{c_{2}}{r} \frac{\partial \sigma_{r r}}{\partial \theta}-\frac{2}{r} \tau_{r \theta}-\frac{b_{22}}{r^{2}} \frac{\partial u_{r}}{\partial \theta}-\frac{b_{12}+b_{66}}{r} \frac{\partial^{2} u_{z}}{\partial z \partial \theta}-b_{66} \frac{\partial^{2} u_{\theta}}{\partial z^{2}}-\frac{b_{22}}{r^{2}} \frac{\partial^{2} u_{\theta}}{\partial \theta^{2}}-c_{3} \frac{\partial \sigma_{r r}}{\partial z}-\frac{b_{26}}{r} \frac{\partial u_{r}}{\partial z}-b_{16} \frac{\partial^{2} u_{z}}{\partial z^{2}}-\frac{b_{26}}{r^{2}} \frac{\partial^{2} u_{z}}{\partial \theta^{2}}- \\
\frac{\partial u_{r}}{\partial r}= & c_{4} \sigma_{r r}-\frac{c_{2}}{r} u_{r}-c_{1} \frac{\partial u_{z}}{\partial z}-\frac{c_{3}}{r} \frac{\partial u_{z}}{\partial \theta}-c_{3} \frac{\partial^{2} u_{\theta}}{\partial z}-\frac{2}{r} \tau_{z \theta}^{0} \frac{\partial u_{r}}{\partial z}-\frac{2}{r} \frac{c_{z \theta}^{0}}{\partial z} \frac{\partial^{2} u_{\theta}}{\partial z \partial \theta} \\
\frac{\partial u_{z}}{\partial r}= & a_{55} \tau_{r z}+a_{45} \tau_{r \theta}-\frac{\partial u_{r}}{\partial z} \\
\frac{\partial u_{\theta}}{\partial r}= & a_{45} \tau_{r z}+a_{44} \tau_{r \theta}-\frac{1}{r} \frac{\partial u_{r}}{\partial \theta}+\frac{1}{r} u_{\theta}
\end{aligned}
$$

so that $\sigma_{z z}^{0}$ and $\tau_{z \theta}^{0}$ are subcritical values of stresses. Since the torsion problem is considered, the stresses $\sigma_{z z}^{0}$ and $\tau_{z \theta}^{0}$ (Lekhnitskiy, 1977; Grigorenko et al., 1991) represented in system (5) are prevailing. This approach indicates the homogeneity of the subcritical stress state of the cylindrical shell.

The next step is to determine the relation between the stresses in the construction. The shell retains an undeformed shape before the stability loss, and in the subcritical phase, the deformation $e_{z z}$ is zero and is described as follows (4):

$$
e_{z z}=a_{11} \sigma_{z z}^{0}+a_{16} \tau_{r \theta}^{0}=0
$$

Hence the relationship between axial and tangent subcritical stresses is:

$$
\sigma_{z z}^{0}=-\frac{a_{16}}{a_{11}} \tau_{r \theta}^{0}
$$


One of the methods to solve the obtained three-dimensional problem (5) is to transform it into a one-dimensional one; for this purpose, we use the Bubnov-Galerkin procedure. Thus, all functions have been developed into trigonometric series in the coordinate along the generatrix $z$ of the cylinder, so that they satisfy the boundary conditions at the ends of the shell

$$
\tau_{z \theta}=\tau_{z \theta}^{0}, \tau_{r z}=u_{z}=0
$$

and we also consider the frequency of functions in a circular coordinate $\theta$ (Grigorenko et al., 1991).

$$
\begin{aligned}
& \sigma_{r r}(r, z, \theta)=\sum_{m=1}^{\infty} \sum_{k=0}^{\infty}\left[y_{1},{ }_{p k}(r) \cos k \theta+y_{1}^{\prime},_{m k}(r) \sin k \theta\right] \cos l_{m} z \\
& \tau_{r z}(r, z, \theta)=\sum_{m=0}^{\infty} \sum_{k=0}^{\infty}\left[y_{2},{ }_{p k}(r) \cos k \theta+y_{2}^{\prime},{ }_{m k}(r) \sin k \theta\right] \sin l_{m} z \\
& \tau_{r \theta}(r, z, \theta)=\sum_{m=1}^{\infty} \sum_{k=0}^{\infty}\left[y_{3},{ }_{p k}(r) \sin k \theta+y_{3}^{\prime}, r_{m k}(r) \cos k \theta\right] \cos l_{m} z \\
& u_{r}(r, z, \theta)=\sum_{m=1}^{\infty} \sum_{k=0}^{\infty}\left[y_{4},{ }_{p k}(r) \cos k \theta+y_{4}^{\prime}, r_{m k}(r) \sin k \theta\right] \cos l_{m} z \\
& u_{z}(r, z, \theta)=\sum_{m=0}^{\infty} \sum_{k=0}^{\infty}\left[y_{5}, p k(r) \cos k \theta+y_{5}^{\prime}, m k(r) \sin k \theta\right] \sin l_{m} z \\
& u_{\theta}(r, z, \theta)=\sum_{m=1}^{\infty} \sum_{k=0}^{\infty}\left[y_{6},{ }_{p k}(r) \sin k \theta+y_{6}^{\prime},_{m k}(r) \cos k \theta\right] \cos l_{m} z
\end{aligned}
$$

After several mathematical transformations and the separation of variables in equations (5) by means of relations (8), we obtain an infinite system of homogeneous ordinary differential equations of stability in Cauchy normal form:

$$
\frac{d \bar{y}}{d r}=T(r) \bar{y}, T(r)=t_{i, j}(r)
$$

so $\bar{y}=\left\{y_{1},_{p k} ; y_{2},_{p k} ; y_{3},_{p k} ; y_{4},_{p k} ; y_{5},_{p k} ; y_{6},_{p k} ; y_{1}^{\prime},_{m k} ; y_{2}^{\prime},_{m k} ; y_{3}^{\prime},_{m k} ; y_{4}^{\prime},_{m k} ; y_{5}^{\prime},_{m k} ; y_{6}^{\prime},{ }_{m k}\right\}$ is the solving vector function, and the matrix $T(r)$ consist of non-zero elements of the coefficients for unknown vector functions $\bar{y}$, which are considered in (Semenyuk et al., 2019).

The implementation of the obtained system of stability equations (9) with the given boundary conditions (7) is carried out using the numerical method of discrete orthogonalisation (Grigorenko et al., 1991). The solving algorithm for the problem of rotating shell stability under the end shear stress has been developed as a software package of applications for the personal computer.

\section{RESULTS AND ANALYSIS OF NUMERICAL CALCULATIONS}

Experimental testing and implementation of the capabilities of the proposed approach determine the consideration of the circular cylindrical shell stability to torque. The shell is formed by winding and has the given geometric and mechanical characteristics: the inner radius $R_{1}=0.585 \mathrm{~m}$ and outer $R_{2}=0.615 \mathrm{~m}$ of 
the surfaces, the length $L=1.2 \mathrm{~m}, E_{z}=1,900 \mathrm{MPa}, E_{\theta}=1,200 \mathrm{MPa}, E_{r}=450 \mathrm{MPa}, G_{z r}=G_{\theta r}=230 \mathrm{MPa}$, $G_{z \theta}=300 \mathrm{~Pa}, v_{z \theta}=0.15, v_{r \theta}=0.3, v_{r z}=0.07$. Figure 2 shows the graphs at the axes points $\tau_{z \theta}^{c r}-\psi$, where $\tau_{z \theta}^{c r}$ is the critical value of the shell shear stress (vertical axis), and the divergence of the reinforcement directions and the axis of the shell is determined by the angle $\psi$ (horizontal axis).

In Figure 2, curve 1 is derived for a single-layer shell, curve 2 is for a two-layer cross-wound shell, and curve 3 is obtained by solving the system of equations (9) at subcritical stresses $\sigma_{z z}^{0}$ and $\tau_{z \theta}^{0}$ which are calculated by the method presented in (Lekhnitskiy, 1977); directions $z$ and $\theta$ are analysed in Figure 1.

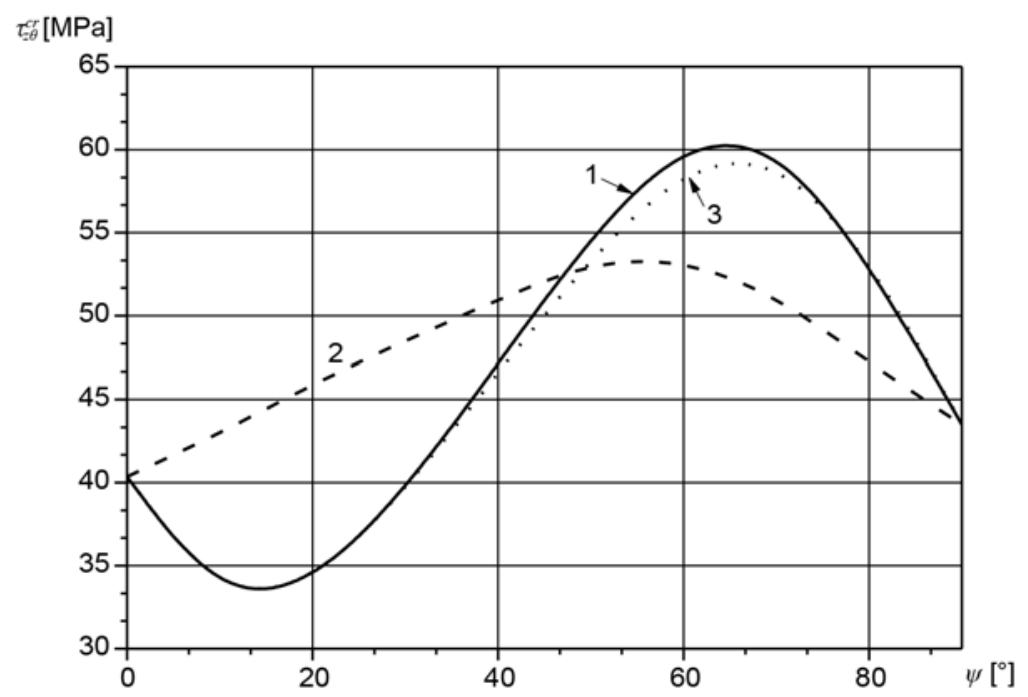

Fig. 2. The dependence of the cylinder shear stresses on the angle of rotation of the main directions of the material elasticity

The analysis of the results shows that the critical values for a one-layer shell are calculated using subcritical stresses $\sigma_{z z}^{0}$ and $\tau_{z \theta}^{0}$ which were obtained according to solutions (6) and are consistent with the given critical values taking into account the subcritical stresses (Lekhnitskiy, 1977). It is also proved that layering of the shell plates significantly affects the cylinder stability at different angles of laying composite material - curves 1 and 2 (Fig. 2).

\section{CONCLUSIONS}

Thus, a solution of the problem of stability of the circular cylindrical shells under torque has been found, taking into account the anisotropy of the material with one plane of elastic symmetry, derived in the spatial formulation. A solvable system of differential equations of stability is obtained based on three-dimensional relations within the theory of elasticity. Using the proposed approach, the dependence of the critical values of the shear stresses on the reinforcement angle of the cylindrical shell is investigated. 


\section{REFERENCES}

Bazhenov, V. A., Semenyuk, M. P. \& Trach, V. M. (2010). Nelshshne deformuvannya, stshyust' $i$ za-krytychna povedshka ashzotropnykh obolonok [Nonlinear deformation, stability and supercritical behavior of anisotropic shells]. Kyiv: Karavela.

Grigorenko, Ya. M., Vasilenko, A. T. \& Pankratova, N. D. (1991). Zadachi teorii uprugosti neodnorodnykh tel [Problems of the theory of elasticity of inhomogeneous bodies]. Kyiv: Naukova Dumka.

Guz', A. N. \& Babich, I. Yu. (1985). Prostranstvennyye zadachi teorii uprugosti i plastichnosti. T. 4. Trekhmernaya teoriya ustoychivosti deformiruyemykh tel [Spatial problems of the theory of elasticity and plasticity. Vol. 4. Three-dimensional theory of stability of deformable bodies]. Kyiv: Naukova Dumka.

Kardomateas, G. A. (1995). Bifurcation of Equilibrium in Thick Orthotropic Cylindrical Shells under Axial Compression. Journal of Applied Mechanics, 62 (1), 43-52. doi: 10.1115/1.2895882

Kardomateas, G. A. \& Philobos, M. S. (1995). Buckling of Thick Orthotropic Cylindrical Shells under Combined External Pressure and Axial Compression. AIAA Journal, 33 (10), 1946-1953. doi: 10.2514/3.12750

Lekhnitskiy, S. G. (1977). Teoriya uprugosti anizotropnogo tela [Theory of elasticity of an anisotropic body]. Moskva: Nauka.

Novozhilov, V. V. (1948). Osnovy nelineynoy teorii uprugosti [Fundamentals of the nonlinear theory of elasticity]. Leningrad - Moskva: OGIZ.

Semenyuk, N. P., Trach, V. M. \& Podvornyi, A. V. (2019). Spatial Stability of Layered Anisotropic Cylindrical Shells under Compressive Loads. International Applied Mechanics, 55, 211-221. doi: 10.1007/s10778-019-00951-5

Trach, V. M., Semenyuk, M. P. \& Podvornyi, A. V. (2019). Vykorystannya 3D metodyky do rozrakhunku napruzhenoho stanu sharuvatykh anizotropnykh tsylyndrychnykh obolonok pid diyeyu bokovoho tysku [The use of 3D technique to calculate the stress state of layered anisotropic cylindrical shells with side pressure]. In Resursoekonomni materialy, konstruktsiyi, budivli ta sporudy [Resource-efficient materials, structures, equipment]. Vypusk 37 (pp. 296-306). Rivne: NUVHP.

\section{STATECZNOŚĆ ANIZOTROPOWYCH POWŁOK CYLINDRYCZNYCH POD WPŁYWEM SKRECCANIA W POŁOŻENIU PRZESTRZENNYM}

\section{STRESZCZENIE}

W przedstawionej pracy uzyskano nieskończony układ jednorodnych równań różniczkowych w rozkładzie normalnym Cauchy'ego, aby rozwiązać problem stateczności anizotropowych warstwowych powłok cylindrycznych pod wpływem oddziaływania zewnętrznego momentu skręcającego według relacji przestrzennych przewidzianych w teorii sprężystości. Składowe stanu naprężenia, które są niezbędne do rozwiązania układu równań, uzyskano w drodze analitycznej z użyciem uogólnionego prawa Hooke’a. Wyniki uzyskano dla cylindra jednowarstwowego i porównano $z$ wartościami obciążeń krytycznych obliczonymi z użyciem dobrze znanej metody zaproponowanej przez Lekhnitskiego. Sugerowane podejście można zastosować na przykład w celu rozwiązania problemu stateczności dwuwarstwowej cylindrycznej powłoki pod wpływem momentu skręcającego, który jest określany poprzez obliczenie naprężenia ścinającego.

Słowa kluczowe: cylinder, stateczność, anizotropia, skręcanie, formowanie przestrzenne 